\title{
Physiological and Psychological Determinants of Quality of Life for Patients after Cardiac Surgery and the Associated Factors
}

\author{
Rana Akram Rawashdeh'1, Jafar Alasad Alshraideh ${ }^{2}$ \\ ${ }^{1}$ Royal Medical Services, Amman, Jordan \\ ${ }^{2}$ School of Nursing, University of Jordan, Amman, Jordan \\ Email: ranarawashdeh@yahoo.com
}

How to cite this paper: Rawashdeh, R.A. and Alshraideh, J.A. (2019) Physiological and Psychological Determinants of Quality of Life for Patients after Cardiac Surgery and the Associated Factors. Open Journal of Nursing, 9, 1022-1040.

https://doi.org/10.4236/ojn.2019.910076

Received: September 11, 2019

Accepted: October 26, 2019

Published: October 29, 2019

Copyright $\odot 2019$ by author(s) and Scientific Research Publishing Inc. This work is licensed under the Creative Commons Attribution International License (CC BY 4.0).

http://creativecommons.org/licenses/by/4.0/

\begin{abstract}
Purpose: This review related to the level of health-related quality of life (HRQOL) and post-traumatic stress disorder symptoms (PTSD) for patients after cardiac surgery, and associated risk factors. Also the HRQOL, PTSD measures and the related factor. Methods: The search strategy was guided by the review aims. The following databases were searched to retrieve related literature: the Cumulative Index to Nursing and Allied Health Literature (CINAHL) via EBSCO, MEDLINE via PubMed, Ovid, Science Direct, Google Scholar, in addition to the Jordanian Database for Nursing Research. Studies presented in English for the period between 2012 and 2019 were included. Literature was reviewed by using the following strategy: The key word "post-operative HRQOL", "post-operative PTSD", "prevalence", "incidence", "risk factors", and "cardiac surgery", with using of Boolean operators "AND", "OR", and "NOT" to conduct the search in databases, Then the titles and abstracts were reviewed for their relevancy and irrelevant and duplicated studies were discarded. EBSCO resulted in 180 articles, Ovid 5 articles, and SCIENCE DIRECT 200 articles, articles with the same ideas were sorted, and full text was included in the review. The overall number after sorting was 25 articles that were included in the review. Results: Literature has aggregated the most common risk factors as age, gender, marital status, social support, medical comorbidities, smoking, alcohol use, ICU environment, surgery techniques and physiological indicators, and the most important is preoperative HRQOL level. Also, the researcher highlighted several important points related to PTSD after cardiac surgery. Firstly, PTSD appears to be present in approximately $10 \%$ of the post-cardiac surgical population, with some estimates reaching as high as $38 \%$. ICU care, fright at the time of the event, perceived threat to life, high levels of sedation and social isolation may all contribute to
\end{abstract}


this developing PTSD. Patients with PTSD are susceptible to poor outcomes following surgery including greater physical complication, psychological problems, increased morbidity and mortality, affecting the quality of life and well-being. For the purpose of this study, specified risk factors related to PTSD development after cardiac surgery will be studied concerning demographics, social, medical, psychological, and environmental. Conclusion and Recommendation: HRQOL and PTSD is an important indicator to measure the outcome of cardiac surgery on a short and long term. Researchers should be aware of the effect of various related factors that could affect the improvement of this outcome.

\section{Keywords}

HRQOL, PTSD, CABG, Associated Factors

\section{Introduction}

Heart diseases in general and Coronary Artery Disease (CAD) in specific are considered one of the major causes of morbidity, hospitalization, and mortality worldwide [1]. Coronary Artery Disease is responsible for 30\% of deaths in developing and developed countries above the age of 35 , and for $50 \%$ in western countries [1] [2], with huge worldwide disability and mortality [3] [4]. Coronary artery bypass grafting $(\mathrm{CABG})$ is one of the primary surgical treatment for this disease [5]. Literature findings indicate that patients undergoing cardiovascular surgery can have benefits in improving QOL, especially in matters of functional, physical, pain, general health, vitality and emotional [1] [3]. Cardiac surgeries can improve survival, reduce disability, and improve physical and psychological ability [4] [5].

In other studies, cardiac surgery contributes to prolonged or poor recovery; and as a result has negative consequences on morbidity, mortality, health-related quality of life (HRQOL) [6], developing psychological and post-traumatic stress disorder (PTSD) symptoms [7].

Patients post cardiac surgeries report problems of physical activity, social interaction, sleep disturbances, psychological, and cognitive domains which in turn affect HRQOL, and as a result, affect morbidity and mortality outcomes [8] [9]. Cardiac surgeries have positive outcomes on HRQOL [10], psychological outcomes [6] [8]. All of these outcomes have an effect on long term recovery after cardiac surgeries, and they are related in term of affecting each other's in both positively and negatively. Patients' recovery after cardiac surgeries in term of quality of life is related to risk factors which had been supported in literature to include: individual's characteristics, developmental characteristics, biological, psychological, and environmental [9].

From that it's obvious following HRQOL outcomes in cardiac patients after surgery, help health team members interfere and manage these negative conse- 
quences that affect health and well-being of patients, their families, and the communities they live in. Up to the researcher's knowledge, there were no study to assess the level of HRQOL and emotional change during the first month after cardiac surgery, and the associated factors related to HRQOL after cardiac surgery.

\subsection{Methods}

The search process directed towards articles published in journals that identified study key words. The search was conducted using the following online databases: the Cumulative Index to Nursing and Allied Health Literature (CINAHL) via EBSCO, MEDLINE via PubMed, Ovid, Science Direct, Google Scholar, in addition to the Jordanian Database for Nursing Research. The keywords which have been used were "HRQOL", "PTSD", "CABG", and "Associated factors". Boolean operators (AND, OR) have been applied separately and in combination with the keywords to expand, combine, or exclude keywords in a search for obtaining more specific results. The reviewed studies focused on HRQOL and associated factors after CABG surgery, and/or PTSD and associated factors associated after CABG surgery. The related articles were selected for a deep understanding of the level and associated factors of HRQOL and PTSD after CABG surgery.

\subsection{Inclusion Criteria}

The selected articles in this review were limited to: English language articles, published in nursing and non-nursing journals, period of publication range from 2012-2019; full text was only selected; abstract, and reports were excluded from review.

\subsection{Search Strategy Outcomes}

The titles and abstracts were reviewed for their relevancy and irrelevant and duplicated studies were discarded. EBSCO resulted in 180 articles, Ovid 5 articles, and SCIENCE DIRECT 200 articles, articles with the same ideas were sorted, and full text was included in the review. The overall number after sorting was 25 articles that were included in the review.

\section{Results}

The relevant articles involved were 25 . The total preliminary articles were 285 articles divided into: 225 articles for HRQOL after CABG and associated factors, and 160 articles for PTSD after CABG and associated factors. First, we removed the non-English language from the results (the total number for HRQOL was 198, and for PTSD were 150), after that the duplicates were omitted resulting in 125 for HRQOL, and 103 for PTSD. Then sorting the articles by titles; 80 for HRQOL, and 26 for PTSD were included and sorted for abstracts yielding 30, and 26 articles consecutively. Finally excluding non-research articles the total numbers of articles included in the review were 25 (15 for HRQOL and 10 for 
PTSD). The results of the articles were discussed into two major themes: HRQOL after CABG and associated factors, and PTSD after CABG and associated factors. Figure 1 explains the search strategy outcomes as a flow chart below.

\subsection{HRQOL after Cardiac Surgery and Related Factors}

Cardiac surgery is performed for treating cardiac disease, restore normal life function, and expand the quality of life [1]. Health-related quality of life (HRQOL) is an important part of assessing the outcome of cardiac surgery [2]. HRQOL after cardiac surgery has been studied in literature for the level of improving, associated risk factors, and its relationship with other physical and psychological outcomes. In general, HRQOL improves after cardiac surgery [1] [3], but $8 \%-19 \%$ of patients experience a decline in HRQOL as an outcome after surgery [3]. Cardiac surgery is very effective at releasing angina and improving survival. Traditional outcome measures assessing the quality of cardiac surgery have been morbidity and mortality. But, with improvements in perioperative care, the overall mortality associated with cardiac surgery has dropped

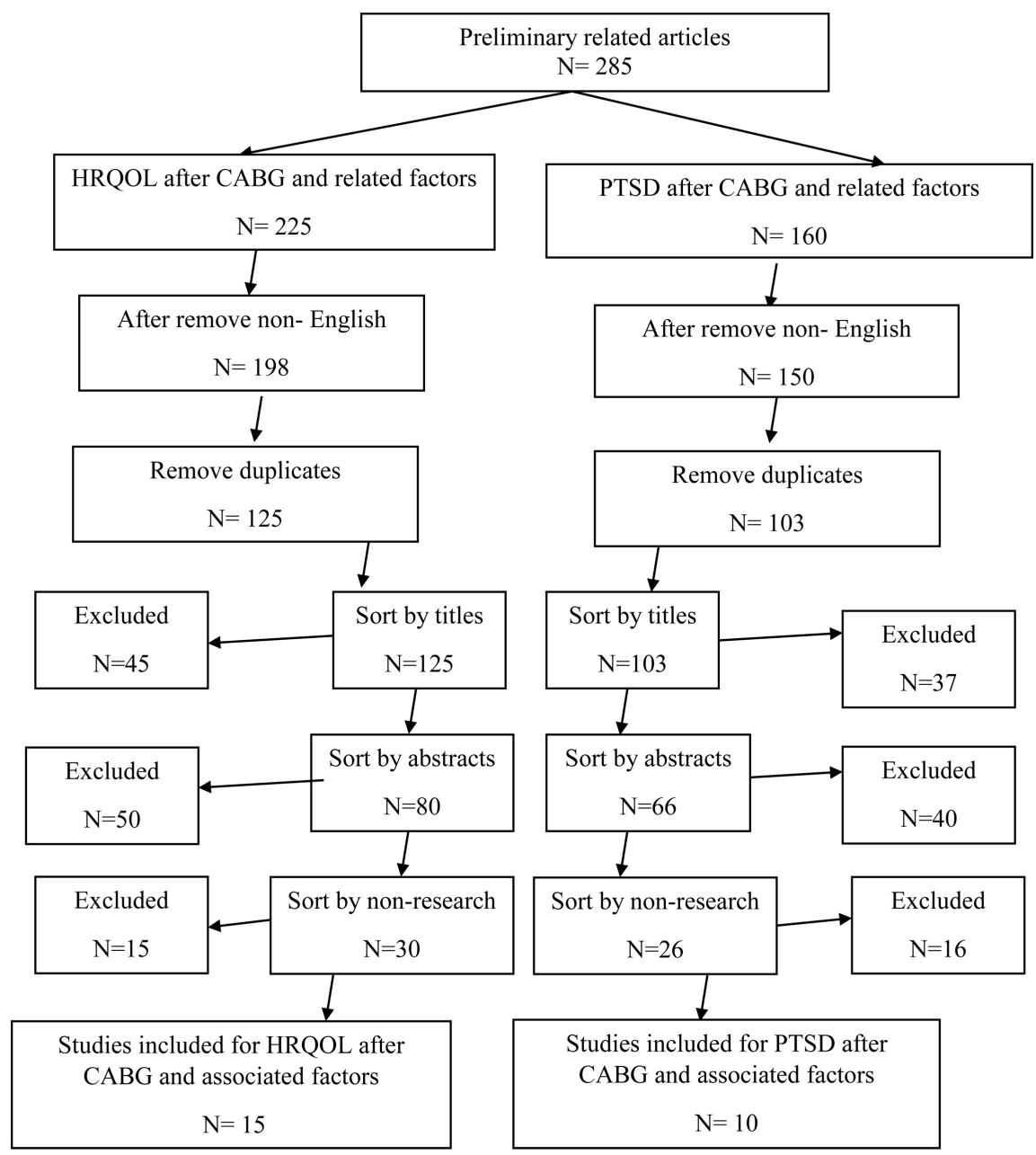

Figure 1. Search strategy outcomes. 
despite an increasingly elderly and patients of high risk. Furthermore, long-term mortality has limited use as an outcome measure [4]. Negative emotional and sleep consequences may happen as a result of cardiac surgery which affects the quality of life for these patients [1].

Health-related quality of life defined by Wilson and colleagues (1995) includes the "dimensions of physical capacity, social functioning, mental health and, general health perceptions and incorporates such concepts as vitality, pain and cognitive functioning" [4]. When assessing health-related quality of life; a multi-dimensional aspect of an individual's perception of the physical, psychological and social aspects of life taking into consideration and can be affected by a disease process and its treatment [4].

A study performed to evaluate the impact of cardiac surgery on HRQOL of elderly patients after three and six months by individual interviews in the pre and postoperative periods (after three and six months) by telephone using SF-36 [5]. Of the 44 individuals evaluated, a significant increase in the average of the SF-36 scores between pre and post-surgical periods (three and six months) for the domains: functional capacity, pain, general health, vitality and emotional aspect [5]. A contrary finding resulted in a study by Kaur, Kumar, \& Kumari (2013). The findings of the study indicated that the mean of quality of life before CABG is higher than the means of quality of life after CABG [6].

Tremendous studies in the field of HRQOL after surgery assess the level of HRQOL among patients after cardiac surgery, compare the result with the pre-surgical level of HRQOL, and investigated the related risk factors that affect the improvement of HRQOL after cardiac surgery.

Preoperative HRQOL in literature considered to be the most important predictor of post HRQOL in patients post-cardiac surgery as in a study performed to compare the differences in HRQOL of patients before and after cardiac surgery [2]. Kurfirst and colleagues (2014) conducted a prospective observational study on cardiac patients to assess the HRQOL questionnaire before and after one year after surgery using the SF-36. The result showed a significant improvement in all of the eight dimensions, and the higher preoperative HRQOL status considered the only significant factor of possible non-improvement of postoperative HRQOL [2]. The same result was supported in a study by Verwijmeren and colleagues (2018) who studied the relationship between preoperative factors and change in HRQL one year after CABG. The most important risk factor for change in the level of HRQL was the preoperative level of HRQL [7]. In contrast to a study that didn't find a significant association between pre-HRQOL and post-surgery level in patients after cardiac surgery [8]. The preoperative HRQOL assessment should be an important part of the preoperative assessment in general. The findings lead to conclude that older patients with relatively higher cardiac operative risk have lower preoperative HRQOL, but they are more likely to exhibit significant improvement in HRQOL postoperatively. If patients received more gentle operative techniques and appropriate postoperative care, 
then a significant reduction in the number of postoperative complications and mortality will profit, and improvement in their HRQOL [2].

Age plays an important role in determining the level of improvement of HRQOL after cardiac surgery. Some studies found older adults have improved HRQOL level after cardiac surgery in comparison to pre HRQOL level [2] [4] [9] [10]. Other studies found no differences in HRQOL level among different age groups [11], while others found being old and confronted to high-risk situation lower your HRQOL after cardiac surgery [12] [13].

In relation to gender, female patients who underwent cardiac surgeries are at greater HRQOL improvement than male patients, while other studies found the contrary [9] [14], other studies considered male sex is a predictor of improving the level of HRQOL after surgery [1] [10], and some studies found no significant differences in HRQOL level in both sex after cardiac surgery [11].

Physical capacity and physical function play an important role in improving HRQOL after cardiac surgery in literature, after considering the preoperative level of HRQOL as the major determinant of post HRQOL level after cardiac surgery. Older patients with low functional capacity before surgery had a more significant improvement in physical capacity and HRQOL after cardiac surgery [9].

Other risk factors were explored in literature to include Sociodemographic, medical comorbidities, and others. Ai and colleagues (2013) compared the HRQOL between patients after mitral valve repair (MvRp) and mitral valve replacement (MVR). The prospective study consists of 56 patients. (42.8\%) of these patients had MVR while (57.1\%) of them had MvRp. The HRQOL was evaluated according to the Turkey version of the (SF-36) before and after 6 months of the operation. The result indicated no significant difference between the groups in terms of physical role functioning (PR), and the social role functioning values $(\mathrm{SF})$. However, the changes in physical functioning (PF), bodily pain (BP), general health (GH), vitality (VT) and restraints on emotional role functioning (RE) and mental health $(\mathrm{MH})$ values were significant and being higher in the MvRp group than in the MVR group [9]. Ai and colleagues (2013) considered age (older), gender (female), functional capacity, rhythm, HTN, DM, applied surgical method, Echo result as the related risk factors that contributed to the changes in HRQOL after cardiac surgery.

On-pump and off-pump type surgery were compared in the term of HRQOL in patients after cardiac re surgery in 40 patients in Germany using SF-36. Prospective three years follow study revealed that the HRQOL in both groups was the same in relation to differences blood loss, surgery duration ICU stay, mechanical ventilation, \& blood transfusion [9] [15]. The result indicated no differences in term of HRQOL between on-pump and off-pump technique.

Effect of rehabilitation programs and special care were examined in this study through examine HRQOL after CABG in patients and partners after involved in a rehabilitation program after surgery. Physical function improved after an in- 
tervention, depression level decreased, marital distress didn't change. This gives a conclusion about the effect of a rehabilitation program to improve HRQOL after cardiac surgery [16]. This study conducted to identify factors determines early return to work after six months of CABG. The study identified four new medical factors that could be used as predictors of early return to work after CABG. These factors are: normal serum troponin T level, shorter pump time in surgery, normal mean arterial pressure (MAP) before the surgery and higher serum magnesium $(\mathrm{Mg})$ levels [16].

A study conducted by Peric and colleagues with the aim of examining the predictors of improvement of HRQOL after two years of CABG using the Nottingham Health Profile Questionnaire part one. HRQOL in patients was significantly improved in all domains compared to the preoperative period. The predictors of improvement after CABG were found to be serious angina, sleep, pain, hereditary, male sex, and DM [1].

Another study was conducted to investigate HRQOL of patients underwent CABG after six months and to identify the related risk factors. Data were collected with the SF-36 and socio-demographic characteristics. Gender (male), nationality, occupational status smoking, family status (married), educational status and comorbidities are considered as the related risk factors that affect HRQOL [10].

Irfan, Rahaman, Noman, \& Mithun (2013) conducted a cross-sectional study to assess the HRQOL using SF-36. The findings showed that post CABG patients had a good level of HRQOL an average score of 86. The mental components score was found to be higher than the physical component score. It was found that the association between age and the physical functioning domain of physical component was statistically significant. No statistically significant difference revealed with the different domains of quality of life and socio-demographic characteristics. Overall HRQoL scores in patients with value diseases improve significantly after surgery. The factors of being female and married were a significant predictor of improvement in HRQOL after valve surgery [11] [14].

Another important predictor of HRQOL after cardiac surgery is the ICU environment that could affect patients and interfere with their quality of life level after surgery. The prolonged ICU length of stay lowers the level of functional capacity following surgery, which affects HRQOL level [17]. The study focuses on intervention for patients with more than five days length of stay in ICU and assesses them on three and six months after surgery. Prolonged intensive care unit length of stay following cardiac surgery has worse HRQOL, long-term functional decline and increased dependence on family and other social support systems [17]. In a systematic review elderly patients after CABG are at low risk, and the result supports the conclusion that performing CABG in the elderly may be associated with significant improvements in HRQOL, and the most substantial risk factors were age, social support, medical comorbidities, and ICU length of 
stay for more than 2 days [4].

In an Arab country, a study performed in 250 patients after cardiac surgery from Egypt to compare HRQOL before and after cardiac surgery (one and six months), and the risk factors using SF-36 on a phone for follow up period. The result of the study indicated an improvement in all domains of HRQOL after 6 months of surgery. The related risk factors to affect HRQOL after cardiac surgery: age, gender, education level, marital status, and smoking [18].

As a conclusion, HRQOL is an important indicator to measure the outcome of cardiac surgery on a short and long term. Researchers should be aware of the effect of various related factors that could affect the improvement of this outcome. Literature has aggregated the most common risk factors as age, gender, marital status, social support, medical comorbidities, smoking, alcohol use, ICU environment, surgery techniques and physiological indicators, and the most important is preoperative HRQOL level. Table 1 displays the relevant studies investigated HRQOL after cardiac surgery and the related risk factors.

\subsection{PTSD after Cardiac Surgery: Prevalence and Related Factors}

Post-traumatic stress disorder (PTSD) is a complex condition manifest by symptoms that result from exposure to a traumatic event [19]. According to the fourth edition of the Diagnostic and Statistical Manual of Mental Disorders [19], a diagnosis of PTSD is made when the symptoms persevere for more than one month after the traumatic event(s). PTSD is diagnosed when the symptoms cause clinically significant distress or impairment in a person's life. Criterion A of the DSM-IV-TR suggests that people may be diagnosed with PTSD after suffering armed struggle, physical assault, sexual violence, kidnapping, terror attacks, torture, natural or manmade disasters, motor vehicle accidents or life-threatening illness. While the occurrence of a life-threatening illness is not necessarily considered a traumatic event, incidents related to the illness, which are sudden or tragic, are considered to be triggered [19].

PTSD is a common psychiatric disorder that can affect individuals who experience or witness a life-threatening or violent event (DSM-5, 2013). Individuals with PTSD experience a number of distressing symptoms that categorize into three main symptoms: 1) re-experiencing symptoms such as intrusive thoughts, nightmares or flashbacks; 2) avoiding stimuli or reminders of the event; and 3) physiological arousal (e.g., hypervigilence, exaggerated startle response) [19]. Sensory disturbances can be distressing and have been associated with prolonged psychological distress and heightened physiological arousal [13]. As a result of PTSD, individuals often have reduced social interactions, which impact on quality of life and psychosocial outcomes [19]. As well, individuals with PTSD may experience reduced interest in usual activities and persistent anhedonia. Individuals may have engaged in irresponsible behaviors such as drug taking or excessive alcohol consumption [19]. Further disability is seen in social and family relationships, work attendance, income status, occupational success, education 
Table 1. Summary of studies investigated post cardiac surgery HRQOL.

\begin{tabular}{|c|c|c|c|c|c|c|}
\hline $\begin{array}{l}\text { Authors \& } \\
\quad \text { Year }\end{array}$ & Purpose & $\begin{array}{l}\text { Country } \\
\text { and Sample } \\
\text { Size }\end{array}$ & Design & $\begin{array}{c}\text { Assess- } \\
\text { ment } \\
\text { Tool }\end{array}$ & Result & Associated Risk Factors \\
\hline $\begin{array}{l}\text { (Abah et al., } \\
\text { 2015) }\end{array}$ & $\begin{array}{l}\text { Assess HRQOL } \\
\text { according to age } \\
\text { in octogenarians }\end{array}$ & 44 studies & $\begin{array}{l}\text { Systematic re- } \\
\text { view }\end{array}$ & $\begin{array}{l}\text { SF-36 } \\
\text { HADS } \\
\text { SAQ } \\
\text { Karnofsky }\end{array}$ & $\begin{array}{l}\text { HRQOL improved, } \\
\text { however there was } \\
\text { minority in whom } \\
\text { quality of life } \\
\text { declined ( } 8 \%-19 \%)\end{array}$ & $\begin{array}{l}\text { Sociodempgraphic, } \\
\text { psychological, } \\
\text { comorbidities }\end{array}$ \\
\hline $\begin{array}{l}\text { (Ay et al., } \\
\text { 2013) }\end{array}$ & $\begin{array}{l}\text { HRQOL after } \\
\text { MVR and MV } \\
\text { Repair }\end{array}$ & $\begin{array}{l}\text { Turkey } \\
56\end{array}$ & $\begin{array}{l}\text { Prospective } \\
\text { before, and after } \\
6 \text { months on } \\
\text { phone }\end{array}$ & SF-36 & $\begin{array}{l}\text { Female, AF, MVR } \\
\text { method affect } \\
\text { physical and mental } \\
\text { QOL negatively ( } \mathrm{p}= \\
0.033, \mathrm{p}=0.003, \& \\
\mathrm{p}=0.015)\end{array}$ & $\begin{array}{l}\text { Age, gender, functional } \\
\text { capacity, rhythm, HTN, } \\
\text { DM, applied surgical } \\
\text { method, Echo result }\end{array}$ \\
\hline $\begin{array}{l}\text { (Baig et al., } \\
\text { 2013) }\end{array}$ & $\begin{array}{l}\text { QOL after CABG } \\
\text { in elderly }\end{array}$ & $\begin{array}{l}\text { USA and } \\
\text { Europe } \\
23 \text { studies, } \\
4793 \text { pts }\end{array}$ & $\begin{array}{l}\text { Systematic } \\
\text { review ( } 20 \\
\text { cohort, } 3 \text { RCT, } \\
14 \text { retrospective, } \\
9 \text { prospective) }\end{array}$ & $\begin{array}{l}\text { SF-20 } \\
\text { SF-36 } \\
\text { SFQ } \\
\text { 15-D } \\
\text { Euro QOL } \\
\text { SAQ } \\
\text { DASI } \\
\text { Karnofsky }\end{array}$ & $\begin{array}{l}\text { Support the } \\
\text { conclusion that } \\
\text { performing CABG } \\
\text { in the elderly may } \\
\text { be associated with } \\
\text { HRQOL } \\
\text { improvements }\end{array}$ & $\begin{array}{l}\text { Age, social life, } \\
\text { comorbidities, ICU length } \\
\text { of stay more than } 2 \text { days }\end{array}$ \\
\hline $\begin{array}{l}\text { (Irfan, } \\
\text { Rahaman, } \\
\text { Noman, \& } \\
\text { Mithun, } \\
\text { 2013) }\end{array}$ & $\begin{array}{l}\text { To assess HRQOL } \\
\text { among CABG }\end{array}$ & $\begin{array}{l}\text { Dhaka } \\
90\end{array}$ & $\begin{array}{l}\text { Cross } \\
\text { sectional }\end{array}$ & $\begin{array}{l}\text { RAND } \\
\text { SF-36 }\end{array}$ & $\begin{array}{l}\text { HRQOL improved } \\
\text { with higher level of } \\
\text { mental domain in } \\
\text { comparison to } \\
\text { physical }\end{array}$ & Age, income, education \\
\hline $\begin{array}{l}\text { (Kaur, } \\
\text { Kumar, \& } \\
\text { Kumari, } \\
\text { 2013) }\end{array}$ & $\begin{array}{l}\text { Assess and } \\
\text { compare HRQOL } \\
\text { before and after } \\
\text { CABG }\end{array}$ & $\begin{array}{l}\text { Punjab } \\
60\end{array}$ & $\begin{array}{l}\text { Exploratory } \\
\text { Comparative } \\
\text { Survey } \\
\text { (before and } 3 \\
\text { months after) }\end{array}$ & $\begin{array}{l}\text { WHO-BRE } \\
\text { F }\end{array}$ & $\begin{array}{l}\text { HRQOL before } \\
\text { CABG is higher than } \\
\text { HRQOL after CABG. } \\
\text { Positive significant } \\
\text { correlation } \\
\text { between HRQOL and } \\
\text { lifestyle before and } \\
\text { after CABG }\end{array}$ & $\begin{array}{l}\text { Educational status, } \\
\text { monthly income, marital } \\
\text { status, lifestyle, gender. }\end{array}$ \\
\hline $\begin{array}{l}\text { (Kurfirst et } \\
\text { al., 2014) }\end{array}$ & $\begin{array}{l}\text { HRQOL before } \\
\text { and after cardiac } \\
\text { surgery, and the } \\
\text { effect of age and } \\
\text { related factors }\end{array}$ & $\begin{array}{l}\text { Prague } \\
310\end{array}$ & $\begin{array}{l}\text { Prospective } \\
\text { consecutive } \\
\text { observational } \\
\text { study } \\
\text { Before and } 1 \\
\text { year after }\end{array}$ & SF-36 & $\begin{array}{l}\text { Older patients show } \\
\text { more improvement } \\
\text { in HRQOL than } \\
\text { younger patients }\end{array}$ & $\begin{array}{l}\text { Preoperative HRQOL, } \\
\text { age, gender, income, } \\
\text { comorbidities }\end{array}$ \\
\hline $\begin{array}{l}\text { (Lavdaniti, } \\
\text { Tsiligiri, } \\
\text { Palitzika, } \\
\text { Chrysomalli, } \\
\text { Marigo, } \\
\text { Drosos, 2015) }\end{array}$ & $\begin{array}{l}\text { Investigate QOL } \\
\text { after CABG and } \\
\text { the related factors }\end{array}$ & $\begin{array}{l}\text { Greece } \\
84\end{array}$ & $\begin{array}{l}\text { Prospective after } \\
6 \text { months }\end{array}$ & SF-36 & $\begin{array}{l}\text { The domains of QOL } \\
\text { that have higher } \\
\text { means are: role } \\
\text { emotional }(68.25 \pm \\
40.71) \text {, role physical } \\
(55 \pm 33.13) \text {, vitality } \\
(53.99 \pm 20.97) \text { and } \\
\text { social functioning } \\
(45.09 \pm 22.71)\end{array}$ & $\begin{array}{l}\text { Gender, nationality, } \\
\text { occupational status } \\
\text { smoking, family status, } \\
\text { educational status and } \\
\text { comorbities }\end{array}$ \\
\hline
\end{tabular}


(Mehrdad et al., 2016)

Factors affect return to work after CABG

Iran

226

(Namazi,

Hosseni, \&

Mohammadi,

2014)

HRQoL before and after valve surgery

Iran

102

Cross

sectional

Before and 2

month after

Analytical

Evaluate the

(Neto et al.,

impact of cardiac surgery on QOL of elderly

Brazil

44

prospective

cohort

Before and

after 3 and 6

months by

phone

QOL 6 months after $\mathrm{CABG}$ and related to age

Peric et al., 2015)

(Peric et al.,

Predictors of 2017) HRQOL after 2 years of CABG

To compare HRQOL before

(Salem, 2013) and after cardiac surgery, and the related risk factors

Compare the

(Usta et al., HRQOL in pts 2013) after cardiac re surgery (on pump vs. off pump

\section{Serbia}

Belgrade, 208 Serbia 243

$\begin{array}{ll}\text { Egypt } & \text { Pre-1 and } 6 \\ 250 & \begin{array}{l}\text { months post } \\ \text { on phone }\end{array}\end{array}$

Early returned to work affect HRQOL positively

RQoL scores in patients with value diseases improve significantly after surgery

Significant improvement in all domains of HRQOL after surgery, with no significant change in physical domain in the follow up

Improvement of QOL was found in older patients. Changes in QOL showed a significant correlation among the patients' age in the sections of physical $(\mathrm{r}=0.18, \mathrm{p}=$ $0.008)$, social ( $r=$

$0.17, \mathrm{p}=0.01)$ and energy $(r=0.21$, $\mathrm{p}=0.002)$

Nottingham health profile questionnaire

HRQOL improved
Socioeconomic occupational, psychological, and medical factors (normal troponin $\mathrm{T}$ level, shorter pump time in surgery, normal mean (MAP) before the surgery and higher serum $\mathrm{Mg}$ levels

Gender, education level, type of valve dysfunction and income

Age, marital status, income, smoking, alcohol
Age, gender, marital status, HTN, smoking, DM, hyper cholesterol, obesity, stress, physical activity
HRQOL improved in all domains after 6 months of surgery
Serious angina, absence of hereditary load, male sex, absence of DM

Age, gender, education level, marital status, smoking

$\begin{array}{llll}\text { Germany } & & \text { SF-36 } & \text { Same HRQOL in } \\ 40 \mathrm{pts} & \text { prospective } & 3 \text { years follow } & \text { both group after 3 } \\ & & \text { up } & \text { years }\end{array}$

Similar HRQOL in relation to differences blood loss, surgery duration ICU stay, Mechanical ventilation, Blood transfusion 


\begin{tabular}{|c|c|c|c|c|c|c|}
\hline $\begin{array}{l}\text { (Verwijmeren } \\
\text { et al., 2018) }\end{array}$ & $\begin{array}{l}\text { Identify } \\
\text { associations } \\
\text { between } \\
\text { preoperative } \\
\text { determinants } \\
\text { and change in } \\
\text { HRQL one year } \\
\text { after CABG }\end{array}$ & $\begin{array}{l}\text { Netherland } \\
658\end{array}$ & $\begin{array}{l}\text { Retrospective } \\
\text { cohort }\end{array}$ & SF-12 & $\begin{array}{l}\text { Physical HRQL } \\
\text { improved in } 22.8 \% \\
\text { of patients, did not } \\
\text { change in } 61.2 \% \text { of } \\
\text { patients and } \\
\text { worsened in } 16.0 \% \\
\text { of patients. Mental } \\
\text { HRQL improved in } \\
49.8 \% \text { of patients, } \\
\text { remained unchanged } \\
\text { in } 34.5 \% \text { of patients } \\
\text { and worsened in } \\
15.7 \% \text { of patients }\end{array}$ & $\begin{array}{l}\text { Preoperative HRQOL the } \\
\text { most significant, others } \\
\text { stroke, AF, DM, age, } \\
\text { gender, medical } \\
\text { comorbidities, } \\
\text { surgical procedures }\end{array}$ \\
\hline
\end{tabular}

levels and general quality of life [20].

Cardiac surgery can be traumatic and stressful, and as a result, many people experience psychological difficulties following treatment. PTSD is now being investigated in post-surgical populations [21] [22]. Patients after cardiac surgery are at high risk of developing post-traumatic stress disorder (PTSD) [13] [21] [22]. These problems occur in up to $15 \%$ and $20 \%$ of the patients, respectively [23], and may hamper full recovery [13] [24].

Prevalence rates for PTSD following cardiac surgery range from $10 \%$ to $38 \%$ [21] [25]. In many cases surgery is performed under emergency conditions following an unexpected cardiac event [25], so the level of PTSD tends to be high (12.7\%); because patients have restricted time to emotionally prepare for the stressed and life-threatening situation. Many patients do not receive adequate information about the emotional consequences of undergoing major surgery. In fact, emotional problems have been documented after cardiac surgery [13] [21] [25].

PTSD levels examined in cardiac population in general, and not merely in cardiac surgery, as well as patients suffer from a cardiac event before underwent cardiac surgery. PTSD is a relatively frequent experience for patients with cardiac syndromes; a recent meta-analysis of 24 acute coronary syndrome (ACS)-induced PTSD prevalence studies showed prevalence estimates varied between $0 \%-32 \%$ [26] and further studies have estimated similar rates (35\%) in implementation of cardio defibrillator device (ICD) [27] and myocardial infarction (17\%) [22], while in CABG (12.7\%) [20] [25].

Edmondson, Richardson, Falzon, Davidson, Mills, and Neria (2012), studied the consequences of developing PTSD after cardiac surgery in a systematic review. The result indicated that cardiac surgery often has a serious and persistent psychological effect [26]. The prevalence rates fell between $8 \%$ and $18 \%$. This was supported in a study conducted to assess posttraumatic stress symptoms (PTSS) and posttraumatic growth (PTG) among heart disease patients [22], the result indicated that $17.1 \%$ of patients had PTSS and $71.2 \%$ patients reported PTG. PTSS were positively associated with PTG and negatively with well-being 
and HRQOL [22]. Hauer and colleagues (2013) examine the effect of a cognitive intervention on PTSD level and their effect on the HRQOL level after one year of cardiac surgery in 126 patients in Germany before, after six and twelve months from ICU discharge by phone. The result supported that cognitive behavioral therapy (CBT) is effective to reduce PTSD after heart surgery and to improve the quality of life [20]. The negative consequences of PTSD in cardiac patients after different cardiac events could be related to physical [28], psychological (Kok et al., 2016), worsening of morbidity and mortality [29].

The time for the assessment of PTSD varies. Some patients experience PTSD immediately after one month following a coronary event [30], three to six month [21] [30] [31], other studies found PTSD remaining at one year to three years [9] [20]. For the purpose of this study initial assessment after one month will be obtained as a baseline for further assessment in the future.

Patients after cardiac surgery, had experienced cardiac comorbidities and various cardiac events before underwent cardiac surgery. These events vary from admission to critical care unit (ICU), general wards, experiencing many procedures (stenting, angiogram, cardio-version, defibrillation, ICD implementation, cardiac arrest, and others), also being in the ICU make patients facing a lot of distressing procedure and confronting stressful environment. The risk factors that will be discussed in this study could be related to any cardiac event since the patients after cardiac surgery could have been facing any cardiac event before the surgery.

Tulloch and colleague (2013) examine several risk factors have been associated with PTSD after cardiac surgery and can be classified as: cardiac event itself risk factors, the surgical process risk factors, the intensive care environment risk factors, medical and psychological comorbidities risk factors, social support, and Sociodemographic factors [29]. This result supported by a study conducted by Kok and colleagues (2016), to found that being male, older age, medical history, psychiatric history, ICU environment and duration of stay, high risk mortality, coping mechanism, smoking and substance abuse, and trait anxiety considered a significant risk factors that affect the development of PTSD in cardiac surgery patients after long-term follow up [13].

Post-traumatic growth, psychological distress, and depression considered strong predictors that affect the PTSD positively [22] [26].

Other studies explore the effect of religious coping strategies, presence of social support, optimistic expectation and hope as a positive predictor for PTSD level after cardiac surgery [9], and they found that being a female, older age, white race, marital status, depression, medical comorbidities as negative predictor of PTSD symptoms.

Emergent surgery plays another important role in developing PTSD after surgery, because of a stressful event, fear from an event, and feeling helplessness [25]. In Boyer and colleagues study (2013) investigated fear appraisal as another risk for developing PTSD in 110 patients awaiting emergency cardiac surgery. 
They observed that PTSD was more prevalent in those who perceived the event as overly life-threatening. Same result in patients with the acute coronary syndrome (ACS), which found that perception of threat, the severity of chest pain, dissociation and intense fear on admission, medical comorbidities are key factors that affect the development of PTSD [30]. The result of this study divided the risk factors into four major factors (peri-traumatic factors through immediate response to an event, internal appraisal and reappraisal process evident through the degree to which threat believed, coping related to social support, and personality traits) [30].

Bhuvaneswar et al. (2014), who studies the effect of beta blockers and hypothesized that the administration of a lipophilic beta-blocker (penetrate the blood-brain barrier and block the receptors) would reduce the symptoms of PTSD. As predicted, patients who received the beta-blocker had $35 \%$ fewer PTSD symptoms than others [27].

The environment of the intensive care unit (ICU) considered as a physical and emotional stressor [20] Whereas physical functioning after cardiac surgery improves over time, mental disorders as a result of high perioperative stress such as chronic anxiety, depression or post-traumatic stress disorder (PTSD) can persist for months and years [13] [20] [21]. The major risk factor for PTSD development in critically ill patients is the presence of traumatic memories from highly stressful experiences during ICU treatment [20]. Distress, anxiety, and fear of death are all common emotional reactions to the surgical environment [21] [25]. Boyer and colleagues (2013) described the ICU environment as being "terrifying" causing distress and psychological morbidities of depression, anxiety, delirium, and PTSD [25].

A study by Davydow, Zatzick, Hough, and Katon (2013) classified the risk factors concerning medical-surgical ICU that cause PTSD into: related to patients (Sociodemographic, medical history, social support, alcohol abuse and smoking, psychiatric history, other fact related to ICU environment (length of stay, mechanical ventilation and duration, number and type of surgery, blood transfusion, sedation, ICU delirium, any related complication). These results are classified into modifiable vs. non-modifiable [31], while others study the risk factors related to ICU environment only [32].

Risk factors include having diabetes mellitus, liver disease, stomach ulcer, gastritis, HIV, arthritis, angina pectoris, tachycardia, hypercholesterolemia, and other heart diseases [26]. The risk of developing cardiovascular risk factors (e.g., hypertension, cardiac hyper reactivity) and coronary artery disease in patients with PTSD have also been established of late [26] [28].

As a summary, the researcher highlighted several important points. Firstly, PTSD appears to be present in approximately $10 \%$ of the post-cardiac surgical population, with some estimates reaching as high as $38 \%$. ICU care, fright at the time of the event, perceived threat to life, high levels of sedation and social isolation may all contribute to this developing PTSD. Patients with PTSD are 
Table 2. Summary of studies investigating post cardiac surgery PTSD.

\begin{tabular}{|c|c|c|c|c|c|c|}
\hline Authors \& Year & Purpose & $\begin{array}{l}\text { Country and } \\
\text { Sample Size }\end{array}$ & Design & $\begin{array}{l}\text { Assessment } \\
\text { Tool }\end{array}$ & Result & $\begin{array}{c}\text { Associated Risk } \\
\text { Factors }\end{array}$ \\
\hline $\begin{array}{l}\text { (Ai, Hall, } \\
\text { Pargament, \& } \\
\text { Tice, 2013) }\end{array}$ & $\begin{array}{l}\text { Explore the } \\
\text { effect of } \\
\text { preoperative } \\
\text { religious coping } \\
\text { on long-term } \\
\text { postoperative } \\
\text { personal growth } \\
\text { and potential } \\
\text { mediation in this } \\
\text { effect }\end{array}$ & $\begin{array}{l}\text { Michigan } \\
481\end{array}$ & $\begin{array}{l}\text { Longitudinal } \\
\text { Twice before } \\
\text { and } 30 \\
\text { months after } \\
\text { surgery by } \\
\text { phone }\end{array}$ & SRGS & $\begin{array}{l}\text { Spirituality may } \\
\text { play a favorable } \\
\text { role in cardiac } \\
\text { patients' } \\
\text { posttraumatic } \\
\text { growth after } \\
\text { surviving a } \\
\text { life-altering } \\
\text { operation }\end{array}$ & $\begin{array}{l}\text { Religious } \\
\text { coping. Medical } \\
\text { indices, } \\
\text { optimistic } \\
\text { expectations, } \\
\text { social support, } \\
\text { and mental } \\
\text { health }\end{array}$ \\
\hline (Bethell, 2014) & $\begin{array}{l}\text { Effect of } \\
\text { psychoeducation } \\
\text { intervention on } \\
\text { PTSD after } \\
\text { cardiac surgery }\end{array}$ & $\begin{array}{l}\text { New Zealand } \\
33\end{array}$ & $\begin{array}{l}\text { RCT } \\
\text { Before and } 3 \\
\text { times after } \\
\text { discharge }\end{array}$ & IES-R & $\begin{array}{l}\text { PTSD range } \\
\text { from } 10 \% \text { - } 15 \% \text {, } \\
\text { and the majority } \\
\text { of participants } \\
\text { who received } \\
\text { the intervention } \\
\text { demonstrated a } \\
\text { reduction in } \\
\text { PTSD symptoms } \\
\text { and an increase } \\
\text { in coping } \\
\text { behaviors r/t } \\
\text { recovery after } \\
\text { cardiac surgery }\end{array}$ & Not discussed \\
\hline $\begin{array}{l}\text { (Bhuvaneswar, } \\
\text { Ruskin, Katzman, } \\
\text { Wood, \& Pitman, } \\
\text { 2014) }\end{array}$ & $\begin{array}{l}\text { To test the effect } \\
\text { of beta blockers } \\
\text { that penetrate } \\
\text { the brain in } \\
\text { lowering the } \\
\text { occurrence of } \\
\text { PTSD after ICD } \\
\text { implementation }\end{array}$ & $\begin{array}{l}\text { USA } \\
18 \mathrm{pts}\end{array}$ & $\begin{array}{l}\text { Cross } \\
\text { sectional }\end{array}$ & PCL & $\begin{array}{l}\text { Pts taking beta } \\
\text { blocker that } \\
\text { penetrating } \\
\text { brain barrier } \\
\text { had less severe } \\
\text { PTSD symptoms } \\
(35 \%) \text { than } \\
\text { patients who had } \\
\text { been taking non } \\
\text { penetrating }\end{array}$ & $\begin{array}{l}\text { Beta blocker } \\
\text { Medical } \\
\text { comorbidities }\end{array}$ \\
\hline $\begin{array}{l}\text { (Bluvstein, } \\
\text { Moravchick, } \\
\text { Heps, Schreiber, \& } \\
\text { Bloch, 2013) }\end{array}$ & $\begin{array}{l}\text { Estimate } \\
\text { posttraumatic } \\
\text { stress symptoms } \\
\text { (PTSS) and } \\
\text { posttraumatic } \\
\text { growth } \\
\text { (PTG) among } \\
\text { heart disease } \\
\text { survivors and } \\
\text { examine if } \\
\text { PTG moderates } \\
\text { the association } \\
\text { between PTSS } \\
\text { and mental } \\
\text { health }\end{array}$ & $\begin{array}{l}\text { Tel-Aviv } \\
\text { Survivors from } \\
\text { MI or CABG } \\
82 \text { pts }\end{array}$ & $\begin{array}{l}\text { Cross } \\
\text { sectional }\end{array}$ & $\begin{array}{l}\text { PTSD } \\
\text { inventory } \\
\text { PTGI } \\
\text { SF-12 } \\
\text { PWB } \\
\text { PD }\end{array}$ & $\begin{array}{l}17.1 \% \text { had PTSS } \\
\text { and } 71.2 \% \\
\text { reported PTG. } \\
\text { PTSS were } \\
\text { positively } \\
\text { associated with } \\
\text { PTG and } \\
\text { negatively with } \\
\text { well-being and } \\
\text { HRQOL. PTG } \\
\text { moderated the } \\
\text { association } \\
\text { between PTSS } \\
\text { and most mental } \\
\text { health outcomes }\end{array}$ & $\begin{array}{l}\text { Posttraumatic } \\
\text { growth } \\
\text { Socio- } \\
\text { dempgraphic }\end{array}$ \\
\hline
\end{tabular}




\section{Continued}

Assessed

pre-surgical

trauma history,

PTS, and

depression;

(Boyer et al., 2013)

and peri-surgical

appraisals of

fear,

helplessness,

and perceived

life-threat after

emergent CABG
Prevalence of

PTSD before

was $12.7 \%$.

total severity

score for

pre-surgical

PTS predicted

fear regarding

the cardiac event

and the

CABG, and

perceived

life-threat

prospective PDS

regarding the

cardiac event

and the CABG.

Pre-surgical

depression

predicted

perceived

helplessness

regarding the

cardiac event

and the CABG,

and $r / t$ to

prediction of

perceived life

threat
Identify risk

factors for

posttraumatic

(Davydow, Zatzick, Hough, \& Katon,

2013)

stress disorder

(PTSD) and

depressive

symptoms after

medical-surgical

intensive care

unit (ICU)
The prevalence

of substantial

PTSD and

depressive

symptoms were

3 months, and

$15 \%$ and $17 \%$ at

12 months
$16 \%$ and $31 \%$ at
Peri surgical

appraisal

Helplessness

Perceived life

threat

Depression
Prevalence

estimate of $12 \%$.

This indicated

that PTSD

the prevalence

(Edmondson,

Richardson, Falzon,

of PTSD in ACS and to quantify

USA

the association 24 study

between $2383 \mathrm{pts}$

ACS-induced

PTSD and

adverse

\section{Systematic PDS \\ review and IES-R \\ meta-analysis \\ Clinical interview}

symptoms

induced by ACS

are prevalent

Not discussed

associated with

increased risk

for recurrent

cardiac events

and mortality

a preoperatively

administered

minimal CBT

reduces $\mathrm{PTSD}$

Not discussed

after heart

surgery and 12

months by

phone
In-hospital acute stress symptoms 


\section{Continued}

(Kok et al., 2016)

(Marke \& Bennett, 2013)

$$
\begin{aligned}
& \text { Investigate } \\
& \text { mediating and/ } \\
& \text { or moderating } \\
& \text { effects of trait } \\
& \text { anxiety on the } \\
& \text { relationship } \\
& \text { between stress } \\
& \text { exposure, and } \\
& \text { PTSD and } \\
& \text { depression in } \\
& \text { relation to } \\
& \text { gender }
\end{aligned}
$$

PTSD,

depression, and trait anxiety present in $10.2 \%$, $13.1 \%$, and 16.3\%. Age, gender, Trait anxiety and stress exposure, stress exposure trait anxiety play important role in the development of PTSD and depression

Netherlands 1125

$\begin{array}{ll}\text { by mail } & \text { inventory } \\ 1.5-4 \text { years } & \text { (SRIP) }\end{array}$

Variables

explained 52 and

$42 \%$ of the

variance in

PTSD symptoms

at each

follow-up. At

1-month

follow-up,

predictors of

PTSD symptoms

were:

Prospective

Before

angiogram, PESI

and 1 and 6

months peri-traumatic

distress, concern

over symptoms,

illness

comprehension,

and lack of social

support. At

6-months

predictors were:

peri-traumatic

distress, lack of

social support,

use of

problem-focused

coping and

continued

symptoms
Event factors, peri-traumatic distress; and maintaining factors including coping strategy, social support, re-appraisal of event threat, and beliefs about the nature of ACS 
matic stress symptoms during the first month after cardiac surgery in QAHI, and to investigate relationships between these variables and associated factors. This review discussed HRQOL as a definition, level after cardiac surgery, and the related risk factors. Also discussed the PTSD as definition, symptoms, level, and related risk factors in patients after cardiac surgery, but in term of association between HRQOL and PTSD in patients after cardiac surgery is not well studied and discussed in literature; the purpose of this study will try to reveal such relation between PTSD and HRQOL, and the related factors associated.

\section{Conflicts of Interest}

The authors declare no conflicts of interest regarding the publication of this paper.

\section{References}

[1] Peric, V., Stolic, R., Jovanovic, A., Grbic, R., Lazic, B., Sovtic, S. and Borzanovic, M. (2017) Predictors of Quality of Life Improvement after 2 Years of Coronary Artery Bypass Surgery. Annals of Thoracic and Cardiovascular Surgery, 23, 233-238. https://doi.org/10.5761/atcs.oa.16-00293

[2] Kurfirst, V., Mokracek, A., Krupauerova, M., Canadyova, J., Bulava, A., Pesl, L. and Adamkova, V. (2014) Health-Related Quality of Life after Cardiac Surgery-The Effects of Age, Preoperative Conditions and Postoperative Complications. Journal of Cardiothoracic Surgery, 9, 46. https://doi.org/10.1186/1749-8090-9-46

[3] Abah, U., Dunne, M., Cook, A., Hoole, S., Brayne, C., Vale, L. and Large, S. (2015) Does Quality of Life Improve in Octogenarians Following Cardiac Surgery? A Systematic Review. BMJ Open, 5, e006904. https://doi.org/10.1136/bmjopen-2014-006904

[4] Baig, K., Harling, L., Papanikitas, J., Attaran, S., Ashrafian, H., Casula, R. and Athanasiou, T. (2013) Does Coronary Artery Bypass Grafting Improve Quality of Life in Elderly Patients? Interactive CardioVascular and Thoracic Surgery, 17, 542-553. https://doi.org/10.1093/icvts/ivt220

[5] Neto, F.J.A.D., Reis, L.M.C.B., Veras, M.R., Queiroz, L.L.C., Nunes, K.D.P.L.N., Miranda, P.D.O., Nunes, J.K.V.R.S., et al. (2015) Impact of Cardiovascular Interventions on the Quality of Life in the Elderly. Brazilian Journal of Cardiovascular Surgery, 30, 626-630.

[6] Kaur, M., Kumar, A. and Kumari, V. (2013) Quality of Life and Lifestyle of Patients before and after Coronary Artery Bypass Grafting (CABG). Journal of Nursing and Health Science, 2, 10-15. http://www.iosrjournals.org

[7] Verwijmeren, L., Noordzij, P.G., Daeter, E.J., van Zaane, B., Peelen, L.M. and van Dongen, E.P.A. (2018) Preoperative Determinants of Quality of Life a Year after Coronary Artery Bypass Grafting: A Historical Cohort Study. Journal of Cardiothoracic Surgery, 13, 118. https://doi.org/10.1186/s13019-018-0798-2

[8] Deutsch, M.A., Krane, M., Schneider, L., Wottke, M., Kornek, M., Elhmidi, Y., et al. (2014) Health-Related Quality of Life and Functional Outcome in Cardiac Surgical Patients Aged 80 Years and Older: A Prospective Single Center Study. Journal of Cardiac Surgery, 29, 14-21. https://doi.org/10.1111/jocs.12233

[9] Ai, Y., Kara, I., Aydin, C., Ay, N.K., Inan, B., Basel, H. and Zeybek, R. (2013) Comparison of the Health Related Quality of Life of Patients Following Mitral Valve 
Surgical Procedures in the 6-Months Follow-Up: A Prospective Study. Annals of Thoracic and Cardiovascular Surgery, 19, 113-119. https://doi.org/10.5761/atcs.oa.12.02234

[10] Lavdaniti, M., Tsiligiri, M., Palitzika, D., Chrysomallis, M., Marigo, M.D. and Drosos, G. (2015) Assessment of Health Status Using SF-36 Six Months after Coronary Artery Bypass Grafting: A Questionnaire Survey. Health Science Journal, 9, 1.

[11] Irfan, S.N., Rahaman, M.M., Noman, A. and Mithun, S. (2013) Health Related Quality of Life among Coronary Artery Bypass Graft Patient Attended at Combined Military Hospital, Dhaka. Anwer Khan Modern Medical College Journal, 4, 10-17. https://doi.org/10.3329/akmmcj.v4i2.16918

[12] Granja, C., Amaro, A., Dias, C. and Costa-Pereira, A. (2012) Outcome of ICU Survivors: A Comprehensive Review. The Role of Patient-Reported Outcome Studies. Acta Anaesthesiologica Scandinavia, 56, 1092-1103. https://doi.org/10.1111/j.1399-6576.2012.02686.x

[13] Kok, L., Sep, M.S., Veldhuijzen, D.S., Cornelisse, S., Nierich, A.P., van der Maaten, J., Hillegers, M.H., et al. (2016) Trait Anxiety Mediates the Effect of Stress Exposure on Post-Traumatic Stress Disorder and Depression Risk in Cardiac Surgery Patients. Journal of Affective Disorders, 206, 216-223. https://doi.org/10.1016/j.jad.2016.07.020

[14] Namazi, P., Hosseni, S.S. and Mohammadi, N. (2015) Health-Related Quality of Life after Valve Replacement Surgery. Journal of Client-Centered Nursing Care, 1, 91-96.

[15] Usta, E., Elkrinawi, R., Ursulescu, A., Nagib, R., Mädge, M., Salehi-Gilani, S. and Franke, U.F. (2013) Clinical Outcome and Quality of Life after Reoperative CABG: Off-Pump versus On-Pump-Observational Pilot Study. Journal of Cardiothoracic Surgery, 8, 66. https://doi.org/10.1186/1749-8090-8-66

[16] Mehrdad, R., Ghadiri Asli, N., Pouryaghoub, G., Saraei, M., Salimi, F. and Nejatian, M. (2016) Predictors of Early Return to Work after a Coronary Artery Bypass Graft Surgery (CABG). International Journal of Occupational Medicine and Environmental Health, 29, 947-957. https://doi.org/10.13075/ijomeh.1896.00798

[17] Barrie, K., Cornick, A., Debreuil, S., Lee, E., Hiebert, B.M., Manji, R.A. and Arora, R.C. (2019) Patients with a Prolonged Intensive Care Unit Length of Stay Have Decreased Health-Related Quality of Life after Cardiac Surgery. Seminars in Thoracic and Cardiovascular Surgery, 31, 21-31. https://doi.org/10.1053/j.semtcvs.2018.07.005

[18] Salem, M. (2013) Health Related Quality of Life of Cardiac Surgery Patients in Alexandria. A Thesis Presented in Partial Fulfilment of the Requirements for the Degree of Master of Public Health Sciences, Alexandria University, Alexandria.

[19] American Psychiatric Association (2013) Diagnostic and Statistical Manual of Mental Disorders. 5th Edition, Author: American Psychiatric Association, Washington DC. https://doi.org/10.1176/appi.books.9780890425596

[20] Hauer, D., Kolassa, I.-T., Laubender, R.P., Mansmann, U., Hagl, C., Roozendaal, B. and Schelling, G. (2013) A Genotype-Specific, Randomized Controlled Behavioral Intervention to Improve the Neuroemotional Outcome of Cardiac Surgery: Study Protocol for a Randomized Controlled Trial. Trials, 14, 89.

https://doi.org/10.1186/1745-6215-14-89

[21] Bethell, F.L. (2014) PTSD and Cardiac Surgery: A Randomised, Controlled Pilot Study to Assess the Effect of a Brief Psychoeducational Intervention. A Thesis Presented in Partial Fulfilment of the Requirements for the Degree of Master of Arts in 
Psychology at Massey University, Auckland.

[22] Bluvstein, I., Moravchick, L., Sheps, D., Schreiber, S. and Bloch, M. (2013) Posttraumatic Growth, Posttraumatic Stress Symptoms and Mental Health among Coronary Heart Disease Survivors. Journal of Clinical Psychology in Medical Settings, 20, 164-172. https://doi.org/10.1007/s10880-012-9318-Z

[23] Tully, P.J. (2013) Quality of Life Measures for Cardiac Surgery Practice and Research: A Review and Primer. Journal of Extra-Corporeal Technology, 45, 8.

[24] Gold, P.W. (2015) The Organization of the Stress System and Its Dysregulation in Depressive Illness. Molecular Psychiatry, 20, 32-47.

https://doi.org/10.1038/mp.2014.163

[25] Boyer, B.A., Matour, S.J., Crittenden, K.B., Larson, K.A., Cox, J.M. and Link, D.D. (2013) Appraisals of Fear, Helplessness, and Perceived Life-Threat during Emergent Cardiac Surgery: Relationship to Pre-Surgical Depression, Trauma History, and Posttraumatic Stress. Journal of Clinical Psychology in Medical Settings, 20, 173-185. https://doi.org/10.1007/s10880-012-9330-3

[26] Edmondson, D., Kronish, I.M., Shaffer, J.A., Falzon, L. and Burg, M.M. (2013) Posttraumatic Stress Disorder and Risk for Coronary Heart Disease: A Meta-Analytic Review. American Heart Journal, 166, 806-814. https://doi.org/10.1016/j.ahj.2013.07.031

[27] Bhuvaneswar, C.G., Ruskin, J.N., Katzman, A.R., Wood, N. and Pitman, R.K. (2014) Pilot Study of the Effect of Lipophilic vs. Hydrophilic Beta-Adrenergic Blockers Being Taken at Time of Intracardiac Defibrillator Discharge on Subsequent PTSD Symptoms. Neurobiology of Learning and Memory, 112, 248-252. https://doi.org/10.1016/j.nlm.2013.12.013

[28] Paulus, E.J., Argo, T.R. and Egge, J.A. (2013) The Impact of Posttraumatic Stress Disorder on Blood Pressure and Heart Rate in a Veteran Population. Journal of Traumatic Stress, 26, 169-172. https://doi.org/10.1002/jts.21785

[29] Tulloch, H., Greenman, P.S. and Tasse, V. (2015) Post-Traumatic Stress Disorder among Cardiac Patients: Prevalence, Risk Factors, and Considerations for Assessment and Treatment. Behavioral Sciences (Basel), 5, 27-40. https://doi.org/10.3390/bs5010027

[30] Marke, V. and Bennett, P. (2013) Predicting Post-Traumatic Stress Disorder Following First Onset Acute Coronary Syndrome: Testing a Theoretical Model. British Journal of Clinical Psychology, 52, 70-81. https://doi.org/10.1111/bjc.12001

[31] Davydow, D.S., Zatzick, D., Hough, C.L. and Katon, W.J. (2013) A Longitudinal Investigation of Posttraumatic Stress and Depressive Symptoms over the Course of the Year Following Medical-Surgical Intensive Care Unit Admission. General Hospital Psychiatry, 35, 226-232. https://doi.org/10.1016/j.genhosppsych.2012.12.005

[32] Wade, D., Hardy, R., Howell, D. and Mythen, M. (2013) Identifying Clinical and Acute Psychological Risk Factors for PTSD after Critical Care: A Systematic Review. Minerva Anestesiologica, 79, 944-963. 